\title{
Preface for article collection "Evolution and variability of Asian Monsoon and its linkage with Cenozoic global cooling"
}

\author{
Ryuji Tada ${ }^{1,2,3^{*}}$, Christian Betzler ${ }^{4}$ and Peter D. Clift ${ }^{2,5}$
}

Keywords: Asian monsoon, Global cooling, IODP, Himalaya and Tibetan Plateau, Indian Ocean, Japan Sea

\begin{abstract}
Although the Asian monsoon (AM) is a regional phenomenon, it exerts a significant impact on global climate. Because uplift of the Himalaya and Tibetan Plateau (HTP) has been considered to play a significant role on the establishment of the AM, numerous attempts have been made to prove the linkage between HTP uplift and AM evolution. On the other hand, comparison of global climate and AM evolution during Cenozoic suggests that AM evolution is significantly affected by global climate. So, it is necessary to evaluate both factors to properly understand the evolution and variability of the AM.

Since the beginning of this century, constraints on the timing and mode of HTP uplift and related onset and spatiotemporal evolution of the AM from terrestrial localities increased drastically. However, information from marine sediments was largely limited to the late Quaternary because no attempt at deep-sea drilling of longer sections in Asia had been made since the end of the last century.
\end{abstract}

From 2013 to 2016, Integrated Ocean Drilling Program/International Ocean Discovery Program (IODP) conducted a series of expeditions that were focused on $\mathrm{AM}$ evolution and its interaction with the wider climate system in the NW Pacific and Indian Ocean regions. In this volume of SPEPS, we introduce some of the new

\footnotetext{
* Correspondence: ryuji@eps.s.u-tokyo.ac.jp

'Department of Earth and Planetary Science, The University of Tokyo, 7-3-1 Hongo, Bunkyo-Ku, Tokyo 113-0033, Japan

${ }^{2}$ Research Center for Earth System Science, Yunnan University, Chenggong

District, Kunming 650500, People's Republic of China

Full list of author information is available at the end of the article
}

results concerning the evolution and variability of the AM during the Neogene obtained from IODP Expeditions 346, 355, and 359 (Tada et al. 2015; Pandey et al. 2016; Betzler et al. 2017).

AM evolution on tectonic time scales is the major topic of this SPEPS. Betzler et al. (2018) examined the relationship between evolution of the South Asian monsoon, global climatic changes, and sea-level changes during the Neogene based on the results of drilling of the carbonate platform of the Maldives in the Indian Ocean by IODP Expedition 359. They found an abrupt change in sedimentation pattern from platform sedimentation to a current-controlled sedimentation at $12.9-13 \mathrm{Ma}$, which they interpret to reflect the abrupt onset of strong monsoon winds. This finding changed our understanding concerning the timing of intensification of monsoon winds that had previously been considered to be $\sim 8.5$ Ma based on increasing abundance of upwelling sensitive planktonic foraminifer Globigerina bulloides in the Arabian Sea (Kroon et al. 1991).

Clift (2017) discussed interactions between AM changes and tectonics in the Western Himalaya based on a comprehensive review of sedimentary records studied in the Himalayan foreland basin and Indus submarine fan, including the result of IODP Expedition 355 from the viewpoint of evolving provenance and weathering. He demonstrated that exhumation of the Greater Himalaya was earlier in the west than in the central Himalaya and peaked in rate in the Middle Miocene, probably due to intensification of the AM. He further demonstrated that exhumation in the Western Himalaya decreased after this time, especially during the 
Late Miocene because of weakening of summer rains possibly due to Late Miocene cooling and southward migration of the ITCZ.

A continuous Neogene sedimentary record of the AM was also obtained from the Japan Sea by IODP Expedition 346. Kurokawa et al. (2019) demonstrated that gamma-ray attenuation (GRA) density of the hemipelagic sediments of the Japan Sea reflects biogenic silica content that changed in association with glacio-eustatic sea-level changes. They established a high-resolution age model covering the last $\sim 12 \mathrm{Myr}$ by tuning a 100-kyrfiltered GRA density profile to short eccentricity cycles for the sediments obtained from IODP Sites U1425 and U1430 in the central and southwestern parts of the Japan Sea. Based on this age model, a hiatus was identified at Site U1430 (water depth $=1072 \mathrm{~m}$ ) from 7 to $\sim 5 \mathrm{Ma}$ corresponding to late Miocene global cooling (Herbert et al. 2016) that may imply intensification of intermediate water production in the Japan Sea during this period.

Matsuzaki et al. (2018) reconstructed shallow-to-deepwater hydrography of the Japan Sea during the MioPliocene based on radiolarian assemblages at Sites U1425 and U1430, and demonstrated that local tectonism and glacio-eustatic sea-level changes influenced the hydrography of the Japan Sea through controlling the position and sill depths of the seaways that connected the basin to the North Pacific. They also demonstrated that late Miocene global cooling and early Pliocene warming significantly affected the hydrography of the sea.

Elemental carbon (EC) in the sediments is considered to reflect biomass burning in the source area that is controlled by the vegetation volume, areal cover, and frequency of lightning. Lu et al. (2018) measured EC in fine $(<2 \mu \mathrm{m})$ and coarse $(>2 \mu \mathrm{m})$ fractions and pollen assemblage of the sediments at IODP Site U1423 in the northeastern Japan Sea covering the last 4.2 Myr. They interpreted EC in the coarse fraction to have come from the Japanese islands whereas that in the fine fraction came from more distant sources. They compared coarse EC with the pollen assemblage and found coarse EC tends to be higher when the climate was wetter. Coarse $\mathrm{EC}$ tends to be higher and shows significant fluctuations after 1.8 Ma suggesting more wet and variable climatic conditions after $1.8 \mathrm{Ma}$.

Orbital to millennial-scale variability of the AM is the other major theme of this SPEPS volume. Kunkelova et al. (2018) analyzed the last $2 \mathrm{Myr}$ in cores from IODP Site U1467 in the Maldives using an XRF core-scanner, and examined aridity cyclical periods on orbital timescales in the low latitudes of the Indian-Asian continent using $\mathrm{Fe} / \mathrm{K}$ ratios. They found $100-$ kyr-like aridity cycles of around $130 \mathrm{kyr}$ frequency in the interval from 1.25 to
$2 \mathrm{Ma}$, which is not present in the LR04 benthic $\delta^{18} \mathrm{O}$ record (Lisiecki and Raymo 2005). They interpreted this as implying increased tilt sensitivity to regional eccentricity insolation changes prior to the Mid Pleistocene Transition (MPT).

The Quaternary sediments of the Japan Sea are characterized by centimeter- to decimeter-scale alternations of dark organic carbon-rich layers and light organic carbonpoor layers that were considered to be the result of millennial-scale changes in salinity and nutrient content of the influx from the East China Sea (ECS), which in turn reflected changes in summer precipitation in South China (Tada et al. 1999). IODP Expedition 346 was planned and seven sites in the Japan Sea and two sites in the northern ECS were drilled to test this hypothesis (Tada et al. 2015). Irino et al. (2018) reexamined core photographs and physical properties; data taken onboard from the seven sites in the Japan Sea in order to revise spliced sequences and associated data sets of physical properties measured onboard. They constructed almost perfectly continuous spliced columnar sections and revised the associated data sets of physical properties that are prerequisite for highresolution paleoclimatic studies of the AM. The revised spliced columnar sections and associated data sets have been used by Tada et al. (2018), Sagawa et al. (2018), Lu et al. (2018), Matsuzaki et al. (2018), and Kurokawa et al. (2019) in this SPEPS.

Tada et al. (2018) constructed a high-resolution age model based on tuning the GRA profile to the LR04 benthic $\delta^{18} \mathrm{O}$ profile during the last $3 \mathrm{Myr}$ at IODP Site U1424 in the eastern part of the Japan Sea where the best paleomagnetic datum and marker tephras are available, thus providing tight age constraints. Subsequently, Tada et al. (2018) correlated individual dark layers between the six deeper sites (U1422, 1423, 1424, 1425, 1426, and 1430) that allowed projection of a high-resolution age model at Site U1424 to the other sites. The result suggests the synchronous deposition of dark layers started at $1.45 \mathrm{Ma}$. Since then, the Japan Sea has responded as a single system to paleoceanographic perturbations.

IODP Site U1427 (water depth $=330 \mathrm{~m}$ ) is located on the southern margin of the Japan Sea where the Quaternary sediments do not show alternation of dark and light layers. Consequently, the high-resolution correlation with dark and light layers of other deeper sites is complex. Sagawa et al. (2018) correlated Site U1427 with Site U1426, $100 \mathrm{~km}$ to the north in the Japan Sea, and Site U1429, $\sim 500 \mathrm{~km}$ to the southwest in the northern ECS using 18 tephra layers. Based on these tephra correlations, they linked the benthic $\delta^{18} \mathrm{O}$ record at Site U1427 with that at Site U1429 to develop a LR04-tuned age model covering the last $0.4 \mathrm{Myr}$. They also demonstrated that the subtle color variations at Site U1427 can be correlated to color variations at Site U1426 over orbital 
time scales, and imported an age model of Tada et al. (2018) from Site U1426 to Site U1427 for the stratigraphic interval covering the last $1.1 \mathrm{Myr}$. The two age models are conformable and orbital-scale correlation was established between Site U1429 in the ESC and all seven Japan Sea sites for the stratigraphic intervals covering the last $0.4 \mathrm{Myr}$. This allowed us to examine the linkage between summer precipitation in southern China and dark and light layers deposition in the Japan Sea through the northeastern ECS.

Summer sea surface salinity (SSS) in the northeastern part of the ECS reflects summer monsoon precipitation in southern China (Kubota et al. 2010, 2015). Kubota et al. (2019) reconstructed temporal changes in summer SSS in the northeastern part of the ECS close to IODP Site U1429 during MIS 3 based on $\delta^{18} \mathrm{O}$ and $\mathrm{Mg} / \mathrm{Ca}$ ratio of planktonic foraminifera Globigerinoides ruber, and demonstrated millennial-scale changes associated with Dansgaard-Oeschger (D-O) cycles, with lower SSS events corresponding to D-O interstadials. Lower SSS events also correspond to dark layers in the Japan Sea sediments, consistent with the conclusions of Tada et al. (1999).

Papers in this collection demonstrate the results of the first round of research from IODP Expeditions 346, 355, and 359 , which serve as the basis for the next stage of work. More research is in progress based on the results presented in this collection. Results from other IODP Expeditions related to Asian monsoon, such as Expedition 353, are also gradually emerging. Integration of the results from all the Asian monsoon related IODP expeditions will be desirable in the next round of analysis and interpretation.

\section{Authors' contributions}

RT wrote the draft of this manuscript, and PDC and CB rewrote and confirmed the contents. All authors read and approved the final manuscript.

\section{Funding}

Not applicable.

\section{Competing interests}

The authors declare that they have no competing interests.

\section{Author details}

'Department of Earth and Planetary Science, The University of Tokyo, 7-3-1 Hongo, Bunkyo-Ku, Tokyo 113-0033, Japan. ${ }^{2}$ Research Center for Earth System Science, Yunnan University, Chenggong District, Kunming 650500, People's Republic of China. ${ }^{3}$ Institute for Geo-Cosmology, Chiba Institute of Technology, 2-17-1 Tsudanuma, Narashino, Chiba 275-0016, Japan. ${ }^{4}$ Institute for Geology, CEN, University of Hamburg, Bundesstrasse 55, 20146 Hamburg, Germany. ${ }^{5}$ Department of Geology and Geophysics, Louisiana State University, Baton Rouge, LA 70803, USA.

Received: 17 August 2020 Accepted: 17 August 2020

Published online: 02 October 2020

\section{References}

Betzler C, Eberli GP, Alvarez Zarikian CA, the Expedition 359 Scientists (2017) Maldives monsoon and sea level. Proceedings of the International Ocean Discovery Program. International Ocean Discovery Program, College Station, p 359. https://doi.org/10.14379/iodp.proc.359.2017
Betzler C, Eberli GP, Lüdmann T et al (2018) Refinement of Miocene sea level and monsoon events from the sedimentary archive of the Maldives (Indian Ocean). Prog Earth Planet Sci 5:5. https://doi.org/10.1186/s40645-018-0165-x

Clift PD (2017) Cenozoic sedimentary records of climate-tectonic coupling in the Western Himalaya. Prog Earth Planet Sci 4:39. https://doi.org/10.1186/s40645017-0151-8

Herbert TD, Lawrence KT, Tzanova A, Peterson LC, Caballero-Gill R, Kelly CS (2016) Late Miocene global cooling and the rise of modern ecosystems. Nat Geosci 9(11):843-847. https://doi.org/10.1038/ngeo2813

Irino T, Tada R, Ikehara $\mathrm{K}$ et al (2018) Construction of perfectly continuous records of physical properties for dark-light sediment sequences collected from the Japan Sea during Integrated Ocean Drilling Program Expedition 346 and their potential utilities as paleoceanographic studies. Prog Earth Planet Sci 5: 23. https://doi.org/10.1186/s40645-018-0176-7

Kroon D, Steens T, Troelstra SR (1991) Onset of monsoonal related upwelling in the western Arabian Sea as revealed by planktonic foraminifers. Proc Ocean Drill Proj, Sci Results 117:257-263

Kubota Y, Kimoto K, Tada R, Oda H, Yokoyama Y, Matsuzaki H (2010) Variations of East Asian summer monsoon since the last deglaciation based on Mg/Ca and oxygen isotope of planktic foraminifera in the northern East China Sea. Paleoceanography 25:PA4205. https://doi.org/10.1029/2009PA001891

Kubota Y, Kimoto K, Tada R et al (2019) Millennial-scale variability of East Asian summer monsoon inferred from sea surface salinity in the northern East China Sea (ECS) and its impact on the Japan Sea during Marine Isotope Stage (MIS) 3. Prog Earth Planet Sci 6:39. https://doi.org/10.1186/s40645-019-0283-0

Kubota Y, Tada R, Kimoto K (2015) Changes in East Asian summer monsoon precipitation during the Holocene deduced from a freshwater flux reconstruction of the Changjiang (Yangtze River) based on the oxygen isotope mass balance in the northern East China Sea. Clim Past 11:265-281. https://doi.org/10.5194/cp-11-265-2015

Kunkelova T, Jung SJA, de Leau ES et al (2018) A two million year record of lowlatitude aridity linked to continental weathering from the Maldives. Prog Earth Planet Sci 5:86. https://doi.org/10.1186/s40645-018-0238-x

Kurokawa S, Tada R, Matsuzaki KM et al (2019) Cyclostratigraphy of the Late Miocene to Pliocene sediments at IODP sites U1425 and U1430 in the Japan Sea and paleoceanographic implications. Prog Earth Planet Sci 6:2. https:// doi.org/10.1186/s40645-018-0250-1

Lisiecki LE, Raymo ME (2005) A Pliocene-Pleistocene stack of 57 globally distributed benthic $\$ 180$ records. Paleoceanography 20(1):PA1003. https:// doi.org/10.1029/2004PA001071

Lu S, Irino T, Igarashi Y (2018) Biomass burning history in East Asia during the last 4 million years recorded in elemental carbon variability at IODP site U1423. Prog Earth Planet Sci 5:53. https://doi.org/10.1186/s40645-018-0206-5

Matsuzaki KM, Itaki T, Tada R et al (2018) Paleoceanographic history of the Japan Sea over the last 9.5 million years inferred from radiolarian assemblages (IODP Expedition 346 Sites U1425 and U1430). Prog Earth Planet Sci 5:54. https://doi.org/10.1186/s40645-018-0204-7

Pandey DK, Clift PD, Kulhanek DK, the Expedition 355 Scientists (2016) Arabian Sea monsoon. Proceedings of the International Ocean Discovery Program. International Ocean Discovery Program, College Station, p 355. https://doi. org/10.14379/iodp.proc.355.2016

Sagawa T, Nagahashi Y, Satoguchi Y et al (2018) Integrated tephrostratigraphy and stable isotope stratigraphy in the Japan Sea and East China Sea using IODP Sites U1426, U1427, and U1429, Expedition 346 Asian Monsoon. Prog Earth Planet Sci 5:18. https://doi.org/10.1186/s40645-018-0168-7

Tada R, Irino T, Ikehara K et al (2018) High-resolution and high-precision correlation of dark and light layers in the Quaternary hemipelagic sediments of the Japan Sea recovered during IODP Expedition 346. Prog Earth Planet Sci 5:19. https://doi.org/10.1186/s40645-018-0167-8

Tada R, Irino T, Koizumi I (1999) Land-ocean linkages over orbital and millennial timescales recorded in late Quaternary sediments of the Japan Sea. Paleoceanography 14:236-247

Tada R, Murray RW, Alvarez Zarikian CA, the Expedition 346 Scientists (2015) Proceedings of Integrated Ocean Drilling Program. IODP, vol 346. Integrated Ocean Drilling Program, College Station. https://doi.org/10.2204/iodp.proc. 346.101

\section{Publisher's Note}

Springer Nature remains neutral with regard to jurisdictional claims in published maps and institutional affiliations. 